\title{
VAN GÖLÜ KAPALI HAVZASINDA YAĞIŞLARIN TREND ANALİZi்
}

\author{
Sevda CoşKUN*
}

Karabük Üniversitesi, Edebiyat Fakültesi, Coğrafya Bölümü, Karabük, Türkiye

\begin{tabular}{l} 
Anahtar Kelimeler \\
\hline Trend Analizi, \\
Mann-Kendall, \\
Yağış, \\
Iklim, \\
Van Gölü.
\end{tabular}

\section{Anahtar Kelimeler}

Íklim

Van Gölü.

\begin{abstract}
Öz
Çalıșmanın alan kapsamını Türkiye'nin Doğu Anadolu Bölgesi'nde Van Gölü kapalı havzası oluşturmaktadır. Van Gölü Kapalı havzası, Türkiye'nin en büyük ikinci kapalı havzasını meydana getirmektedir. Çalışmanın konu kapsamı; havza içerisinde 30 yıldan fazla rasata sahip 7 istasyonun (Van-Bölge, Muradiye, Erçiş, Gevaş, Özalp, Tatvan ve Ahlat) ortalama yağış verilerinin trend analizidir. Havza genelinde uzun yıllar boyunca ölçüm yapan Van-Bölge, Muradiye, Erçiș, Gevaş, Özalp, Tatvan ve Ahlat istasyonlarının aylık ölçülmüş ortalama yağış verileri ele alınarak yıllık ve mevsimlik eğilimlerini analiz etmek araştırmanın amacını oluşturmaktadır. Kapalı havzalarda iklim değişikliğinin etkilerinin daha kolay fark edileceği düşüncesiyle Van Gölü Kapalı havzası alan olarak seçilmiştir. Ayrıca ulusal ve uluslararası literatüre iklim değişikliği ile ilgili bir Türkiye örneğinin daha kazandırılması istenmiştir. Araştırmada yöntem olarak Mann-Kendall Testi, Spearman'ın Rho ve Şen Testi temel alınmıștır. Elde edilen sonuçlara göre Gevaș ve Ahlat istasyonlarında yıllık yağışlarda azalma meydana gelirken, Van-Bölge istasyonunda anlamlı olmayan bir artış görülmüştür. Mevsimlik olarak ise Erciş ve Ahlat istasyonlarında anlamlı bir azalış tespit edilirken Van-Bölge de ise anlamlı olmayan bir artış gözlenmiştir. Muradiye (kış mevsimi hariç) ve Tatvan istasyonlarında ise genel olarak yağışlarda bir eğilime saptanamamıştır. Havza genelinde hem yıllık hem de mevsimlik yağışlarda azalma eğilimi dikkat çekerken Van Bölge istasyonunda ise anlamlı olmayan artış eğilimi görülmektedir.
\end{abstract}

\section{TREND ANALYSIS OF PRECIPITATION IN VAN LAKE CLOSED BASIN}

\begin{tabular}{l}
\hline Keywords \\
\hline Trend Analysis, \\
Mann-Kendall, \\
Precipitation, \\
Climate, \\
Van Lake.
\end{tabular}

\begin{abstract}
The study area comprises of the endorheic basin of Van lake located in the Eastern Anatolia region of Turkey. The Van lake basin formulates Turkey's second-largest closed basin. The subject matter of present study includes trend analysis of average precipitation statistics collected from 7 stations of Van-Region, Muradiye, Erçiş, Gevaş, Özalp, Tatvan and Ahlat with more than 30 years of observation in the basin. The research aims to analyze the annual and seasonal trends of rainfall by collecting monthly measured average precipitation data from Van-Region, Muradiye, Erçiş, Gevaş, Özalp, Tatvan and Ahlat stations that have been measuring the amounts throughout the basin for many years. Mann-Kendall Test, Spearman's Rho and Şen Test were selected as research methods for analysis. According to the results obtained, there was a decrease in annual precipitation in Gevaş and Ahlat stations while an insignificant increase was observed in Van-Region. Seasonally, a significant decrease was detected in Erciş and Ahlat stations, while a insignificant increase was observed in Van-Region. However, the downward trend in both annual and seasonal precipitation is noteworthy across the basin, while a insignificant increase is observed in Van Region station.
\end{abstract}

\section{Alıntı / Cite}

Coşkun, S. (2020). Van Gölü Kapalı Havzasında Yağışların Trend Analizi, Mühendislik Bilimleri ve Tasarım Dergisi, 8(2), 521-532.

\footnotetext{
* ilgili yazar / Corresponding author: sevdacoskun@karabuk.edu.tr, (0370)-418-6457
} 


\begin{tabular}{l|l|l}
\hline Yazar Kimliği / Author ID (ORCID Number) & \multicolumn{3}{|l}{ Makale Süreci / Article Process } \\
\hline S. Coşkun, 0000-0002-4702-4670 & Başvuru Tarihi / Submission Date & 06.02 .2020 \\
& Revizyon Tarihi / Revision Date & 30.04 .2020 \\
& Kabul Tarihi / Accepted Date & 06.05 .2020 \\
& Yayım Tarihi / Published Date & 25.06 .2020 \\
\hline
\end{tabular}

\section{Giriş (Introduction)}

Yağış ve sıcaklık klimatoloji alanında üzerinde en çok araştırma yapılan iki parametre olarak ön plana çıkmaktadır. Bu iki değișkende meydana gelen eğilimler iklim bileșenleri olan litosfer, hidrosfer, kryosfer, atmosfer ve biyosferi son derece etkilemektedir. Küresel ölçekte yapılan araștırmalar sonucunda sıcaklıklarda $0,3{ }^{\circ} \mathrm{C}$ ile $0,6^{\circ} \mathrm{C}$ bir artışın olduğu ileri sürülmektedir Küresel sıcaklığın artmasının ve yağış deseninin değişmesinin küresel iklim değişikliğine neden olduğu düşüncesi artık yaygın olarak kabul görmektedir.

Sıcaklıklarda meydana gelen artışın temel nedeni, atmosfer bileşiminde bulunan gazların yoğunluğundaki değişimlere bağlanmaktadır. Şehirleşmeye bağlı olarak son yıllarda nüfusun arttığı alanlarda önemli sera gazlarından olan $\mathrm{CO}_{2}, \mathrm{CH}_{4}$ ve $\mathrm{N}_{2} \mathrm{O}$ gibi gazların artışıyla şehirlerde, sıcaklık artmakta ve bu alanlarda mikro klima şartları ön plana çıkmaktadır.

Türkiye'deki ortalama sıcaklıklarının uzun dönemli (1930-1993) trend analizleri dikkate alındığında özellikle Doğu Anadolu bölgesinde pozitif yönlü artışlar görülürken, kıyı kesimlerde ise genel olarak bir soğumanın meydana geldiği sonucuna varılmıştır (Türkeş vd., 1995). Sıcaklıklarda meydana gelen eğilimlere bağlı olarak, yağış rejimlerinde de değişimler meydana getirmektedir. Türkiye'de batıdan doğuya doğru gidildikçe yağışlarda artışların olduğu gözlemlenmiştir (Kadıoğlu vd., 1999). Yağışların alansal ve zamansal özelliklerinin incelenmesi sonucunda istatistiki olarak anlamlı eğilimlerin olduğu görülürken yıllık yağışlarda genel olarak bir azalmanın meydana geldiği belirlenmiştir (Türkeş, 1996). Yağıș miktarının azalma gösterdiği bölgeler Akdeniz Bölgesi ve Akdeniz geçiş iklimin yaşandığı alanlarda meydana gelmektedir. Bu durumun; Kuzey ve Kuzey Anadolu görülen orta enlem siklonlarıyla Doğu Avrupa ve Sibirya kaynaklı yüksek basınç alanları ile bağlantılı olduğu düșünülmektedir. Sonuç olarak, özellikle kıș aylarında yağıșlarda negatif eğilimlerin meydan gelmesinin temel nedeni belirtilen durum olarak görülmektedir (Türkeş vd., 2009).

Çalışma kapsamında, Türkiye'nin Doğu Anadolu bölgesinde bulunan Van Gölü Kapalı Havzası ele alınmıştır. Yıllık ortalama yağış değerlerinin 1964-2017 yılları arasındaki eğilimlerinin hangi yönde ve boyutta olduğunu tespit etmek araştırmanın amacını oluşturmaktadır.

Sıcaklık ve yağış parametrelerinde meydana gelen salınımlar, iklimin genel yapısının anlaşılması için önemli ipuçları vermektedir. Bu nedenle iklim değişikliği ile ilgili çalışmalar bu iki parametrenin trend analizlerine odaklanmıştır. Alan yazında konuyla ilgili çalışmalara; (Türkeş vd. 1995; Türkeş, 1996; Tayanç vd., 1997; Kadıŏ̆lu, 1997; Kadıoğlu vd. 1999; Lazaro vd., 2001; Türkeş vd., 2002; Tosic ve Ukasevic, 2005; Karabulut ve Cosun, 2009; Türkeş vd. 2009; Aksoy ve Coşkun, 2010; Coşkun, 2011; Türkeş, 2012b; Erlat, 2013; Yenigün, vd., 2013; Emek, 2014; Addisu, vd. 2015; Ackerman ve Knox, 2015; Soydan, vd., 2016; Sönmez, vd. 2016; Coşkun ve Akbaş, 2017; Asfaw vd., 2017; Rahman, vd., 2017; Polat ve Sunkar, 2017; Nourani, vd., 2018; Su, vd. 2018; Karaosmanoğlu ve Günek, 2018; Aktaș, vd., 2018; Avşaroğlu, 2019; Coşkun, 2019; Şenocak ve Emek, 2019; Şener vd., 2019; Coșkun, 2020a, 2020b) örnek verilebilir.

Çalışmada giriş bölümünden sonra alan yazın tarama örnekleri verilecek, materyal ve yöntem açık olarak anlatıldıktan sonra araştırma bulgularına geçilecektir. En son olarak sonuç ve tartışma kısmı ile çalışma tamamlanacaktır.

\section{Bilimsel Yazın Taraması (Literature Survey)}

Toros (1993), "Klimatolojik serilerden Türkiye İkliminde Trend analizi”; adlı çalıșmasında, iklimde bir değișim olup olmadığını tespit etmek için Türkiye genelini temsilen 18 meteoroloji istasyonuna ait yağış ve sıcaklık verilerini almıştır. İncelenen iklim parametrelerine homojenlik testleri uygulanmıştır. Verilerin normal dağılım sergilediği belirlenmiştir. Çalışmada Sperman Rho ve Men-Kendall mertebe korelasyonu istatistik yöntem olarak uygulanmıștır. Trend analizlerinin sonuçlarına göre Türkiye genelinde incelenen istasyonlarda yüksek sıcaklık ve yağıșta genelde belirgin bir eğilime rastlanmamıştır. Ancak ilkbahar mevsiminin düşük sıcaklıklarında 1950’li ylllarda başlayan ve zamanla artan bir trend gözlenmiștir.

Şen (2013), "Isparta ilinde sıcaklık ve yağış verilerinin eğilim analizi” adlı çalışmada iklim elemanlarından olan sıcaklık ve yağış parametreleri üzerine analizler yapılmıștır. Isparta ilindeki merkez ilçe dâhil 5 istasyonun sıcaklık 
ve yağış verilerine öncelikle non-parametrik analiz yöntemleri olan MannKendall ve Spearman'ın Rho testleri ile analizi gerçekleştirilmiştir. Mann-Kendall ve Sperman analiz sonuçlarına göre yıllık ortalama sıcaklıklarda; Isparta istasyonunda istatistiki açıdan anlamlı artış eğilimleri gözlenirken, yaz mevsiminde tüm istasyonlarda kuvvetli ısınma trendi tespit edilmiştir. Yıllık ortalama maksimum sıcaklıklarda; tüm istasyonlarda anlamlı artış tespit edilmiștir. Kış, ilkbahar, yaz ve sonbahar mevsiminde bütün istasyonlarda ortalama maksimum sıcaklıklarında ısınma eğilimi hâkimdir. Kış yağışlarındaki azalmanın bütün istasyonlarda görülmesi önceki çalışmalarla uyumluluk göstermiştir.

Emek (2014), "Doğu Anadolu bölgesi yıllık ve aylık toplam yağışların trend analizi” adlı çalışmada şu sonuçlara ulaşılmıştır; Doğu Anadolu Bölgesi'ndeki Meteoroloji Genel Müdürlüğü'nün 46 adet yağış gözlem istasyonundan alınan, 1960 ile 2013 yılları arasında değișen, verilere Run testi ile Petitt testi uygulanarak homojenlik analizi gerçekleştirilmiştir. Homojen olduğu belirlenen istasyonlara Mann - Kendall testi ve Spearman'ın Rho testi uygulanarak trend analizi yapılmıştır. Trend analizi sonuçlarına göre; yıllık toplam yağışların \% 95 güven aralığında Baskil, Doğanşehir, Erciş ve Sivrice yağış gözlem istasyonları olmak üzere 4 adet yağıș gözlem istasyonunda, \% 90 güven aralığında ise bunlara ilaveten Ağın ve Elazığ yağış gözlem istasyonları olmak üzere 6 adet yağış gözlem istasyonunda azalan yönde anlamlı trendin varlı̆̆ı gözlenmiştir. Sen'in eğilim metoduna göre ise 28 adet yağış gözlem istasyonunda azalan yönde bir eğilim, 10 adet yağış gözlem istasyonunda da artan yönde anlamlı olmayan bir eğilim gözlenmiştir. Doğu Anadolu Bölgesi'nin kuzey kesimlerinde genellikle artan yönde trend görülürken, güney ve batı kesimlerinde azalan yönde trend tespit edilmiştir. Aylık toplam yağışların trend analizi değerlendirildiğinde ise yaz aylarında genellikle yağışların artan yönde eğilimde olduğu, kış aylarında ise azalan yönde eğilimde olduğu belirtilmiștir. Yazın haziran ayında bölgede azalan yönde bir eğilim saptanmışken, temmuz ayında yerini artan yönde bir eğilime bırakmıştır. Kasım ayı olduğunda ise bölgeye düşen aylık toplam yağışlarda tekrardan azalan yönde eğilim belirlenmiştir.

Kızılelma (2015), “ İç Anadolu Bölgesinde Sıcaklık ve Yağışların Trend Analizi " adlı çalışmada şu sonuçlara ulaşılmıştır. Mann-Kendall ve Sen'in Eğilim Testleri ile Lineer Regresyon Analizi yöntemleri uygulanmıştır. İç Anadolu Bölgesinde bulunan istasyonların sıcaklık ve yağıș parametreleri araștırılmıștır. Parametrik olmayan testler kullanılarak sıcaklıklardaki eğilim analiz edilmiştir. Çalıșmada elde edilen sonuçlar incelendiğinde ortalama, maksimum ve minimum sıcaklıklara anlamlı artışların olduğu tespit edilmiștir.

Kamruzzamana vd. (2016), Estimation of trends in rainfall extremes with mixed effects models" adlı çalışmada; Avustralya'nın güney kesiminde şiddetli yağışların gözlemlenme değişkenliğini şehir planlaması açısından 6 dakikalık şiddetli yağış sürelerinin bilinmesine göre düzenlemiştir. Bu sürelerin bilinmesinin çok önemli olduğunu, yağıșların gözlemlenme değișkenliğinin arttığını fakat yıllık yağıș miktarında bir değișkenliğin olmadı̆̆ını belirtmişlerdir.

Şapolya, (2017) “Ege bölgesi aylık sıcaklık verilerinin bölgesel ortalama Mann-Kendall testi ile trend analizi”; adlı çalışmada, Türkiye'de olası iklim değişikliğinden önemli bir şekilde etkileneceği öngörülen bölgelerden biri olan Ege Bölgesi araştırılmıștır. Bölgedeki 13 istasyonun aylık ortalama sıcaklık (1965-2015) parametrik olmayan Mann-Kendall Sıra Korelasyon Testi ve Bölgesel Ortalama MannKendall Sıra Korelasyon Testi kullanılmıştır. Mann-Kendall testi sonuçlarına göre, nisan-ekim ayları arasında sıcaklıklarda istatistiksel açıdan önemli (\%5 ve \%1 önem seviyesinde) artışların olduğu sonucuna ulașılmıştır. Mevsimlik olarak, artma eğilimi 4 mevsimde de söz konusu iken yaz mevsiminde tüm istasyonlarda önemli bir artma eğilimi gözlenmiştir. Bölgesel olarak incelediğinde sıcaklık değerlerinde önemli artışların mayıs-eylül ayları arasında olduğu, mevsimlik sıcaklık eğilimlerinde ise 4 mevsim için de artma eğilimi olduğu ve bu eğilimlerin kış mevsimi hariç bütün mevsimlerde önemli olduğu belirlenmiştir.

Araştırmaya bir kapalı havzanın konu edilmesi iklim değişikliğinde sıcaklık ve yağış desenlerindeki değişmenin daha kolay fark edilir olmasından kaynaklanmaktadır. Araştırma konusunun seçilmesinde daha önce çalışılmamış olması ve literatüre suptropikal iklim kuşağından bir Türkiye örneğinin daha kazandırılması düşünülmüştür.

\section{Materyal ve Yöntem (Material and Method)}

\section{1. Çalışma Alanı (Study Area)}

Van Gölü kapalı havzası, ortalama yükseltinin en fazla olduğu Doğu Anadolu Bölgesi'nde yer almaktadır. Olușum olarak yaklaşık 13 milyon yıl önce Avrasya ve Arap plakalarının çarpışması sonucu sıkışmaya bağlı olarak meydana gelmiștir (Şaroğlu ve Yılmaz, 1986). Türkiye’nin en büyük gölü olan Van Gölü 3602 km²lik yüzey alanına ve maksimum 451 metre derinliğe sahiptir. \%o 21,7 oranında tuzluluk, $614 \mathrm{~km}^{3}$ lük su hacmi ve 9,7 pH değeri ile sodalı göl olarak dünyanın en büyük gölüdür. Ayrıca havza adını bu gölden almıştır. Geç Pliyosen'de oluşmuş ve Kuvaterner'de etkili olan volkanik olaylar sonucunda bugün ki son şeklini kazanmıştır (Blumenthal vd., 1964; Wong ve Finckh, 1978; Kempe vd., 1978; Degens vd., 1984). Deniz seviyesinden yüksekliği 1648 metre ve su 
toplama havzası, Ercek kapalı havzası da dahil edildiğinde $17.902 \mathrm{~km}^{2}$ alana sahiptir (Altan Aydın, 2017). Van Gölü kapalı havzasının şekillenmesinde tektonik olayların etkisi büyüktür. Havza içerisinde batıya doğru akarsu boyları kısalmakta ve araziyi yüksek morfolojik üniteler kuşatmaktadır. Akköprü (2019), Van Gölü'nün güneybatısındaki akarsular kaynaklarını aldıktan çok kısa bir mesafe sonra göle dökülmektedir. Dicle Nehri su toplama havzası ile Van Gölü su toplama havzası bu alanda birbirlerine çok yaklașmakta olduğunu belirtmiştir. Havza içerisinde doğudan gelen akarsuların boyu daha uzun ve gölü daha çok bu kesimdeki akarsular beslemektedir (Şekil.1).

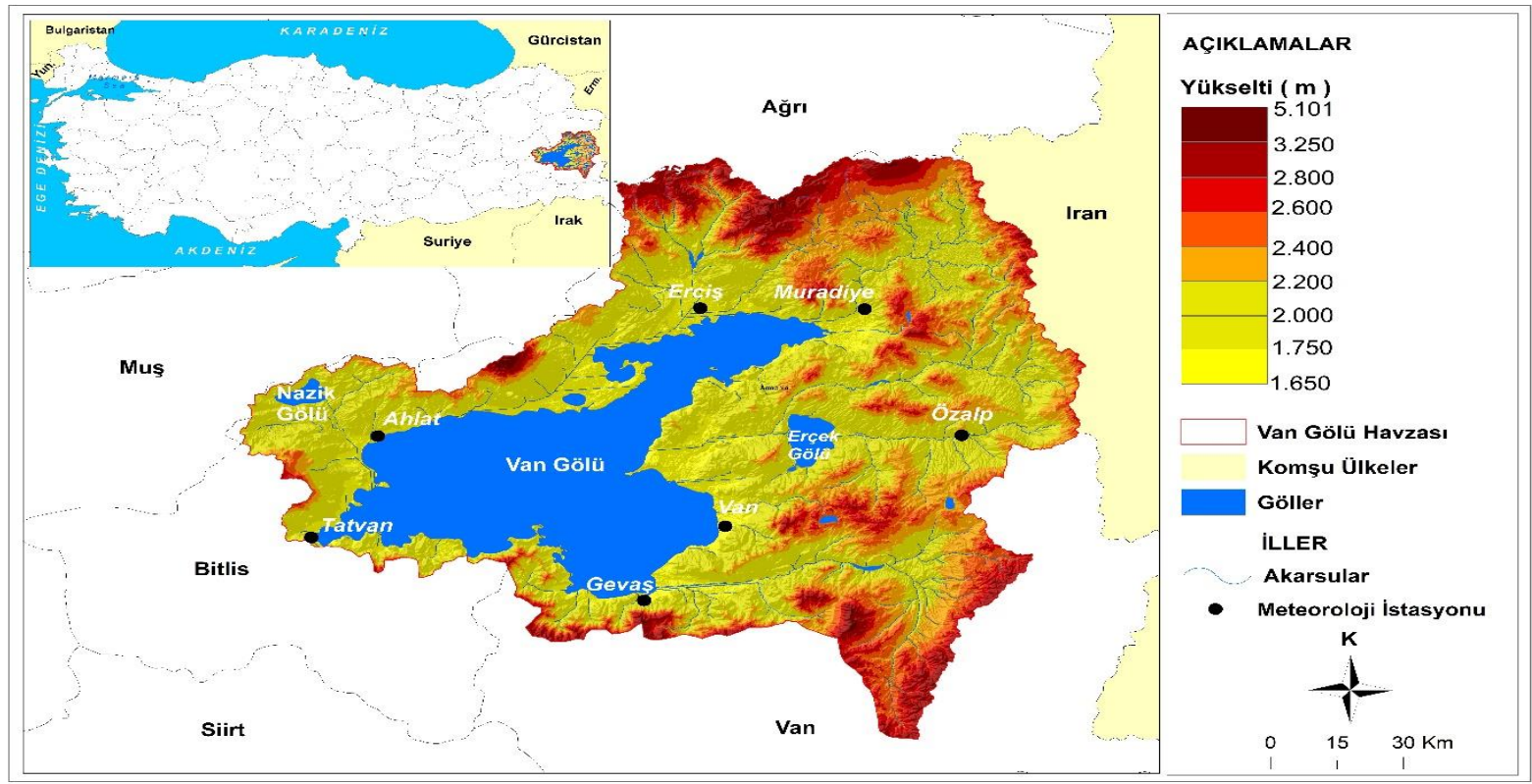

Şekil 1. Araştırma Alanının Lokasyon Haritası (Location Map of the Research Area)

\subsection{Metodolojik Yaklaşım (Methodological Approach)}

Van Gölü kapalı havzasının 1964-2017 yıllarını kapsayan, Van-Bölge, Muradiye, Erçiş, Gevaş, Özalp, Tatvan ve Ahlat istasyonlarının ortalama yağış verileri Meteoroloji Genel Müdürlüğü'nden elde edilmiștir. Trend analizlerinin ve diğer istatistiki analizlerin gerçekleştirilmesinde Trend Analysis for Windows adlı yazılım ve IBM SPSS 24 programından yararlanılmıștır. Kartografik malzemelerin hazırlanmasında ArcGIS 10.3 GIS (Geography Information System) programı kullanılmıştır.

Van Gölü kapalı havzasının 1964-2017 yıllarını kapsayan ortalama yağış parametrelerindeki eğilimlerin hangi yönde ve boyutta gerçekleştiğini ortaya koymak için çeşitli istatistiki yöntemlerden yararlanılarak verilerin uygunluğu tespit edildikten sonra trend analizleri gerçekleştirilmiştir. Trend analiz sonuçlarından daha doğru sonuçlar elde etmek için istasyonların tercihinde en az 30 yıllık kesintisiz veri setine sahip olması dikkate alınmıştır.

İklim değișkenlerin analizinde verilerin uygunluğu önemli bir konudur. Verilerin uygunluğuna bağlı olarak parametrik veya parametrik olmayan yöntemler istatistik işlemlerde kullanılmaktadır. Parametrik olan verilerin zaman serisinde doğrusal regresyonu ele alınırken, var olan eğilimlerin analizi için ise t-testi gibi istatistiki yöntemler tercih edilmektedir. Ancak, Albek (1999), parametrik eğilim analizlerinde iki temel sorun ile karşılaşılmaktadır. Analiz sonuçlarında elde edilen model ve gözlem verileri arasındaki farkların normal dağılmış ve sabit varyanslı olması beklenir. Veri setlerinde uç değerlerin varlığına bağlı olarak, parametrik istatistiki metotlarda oldukça problem oluşturabilmektedir, şeklinde ifade etmiştir. Benzer durumlarla karşılașılmaması adına nonparametrik yöntemler günümüzde en çok tercih edilenler arasındadır. Parametrik olmayan yöntemler verilerin sıralamasını dikkate aldığı için verilerdeki eksiklerden etkilenmeme özelliğine sahiptir. Belirtilen özelliği nedeniyle en çok kullanılan yöntemlerdir. İklim verileri kısa zaman serilerinde hızlı değişimler göstermekte ve sabit kalmamaktadır. Bu özelliği nedeniyle iklim parametreleri homojen dağılış göstermemektedir. Bu özelliğinden dolayı non-parametrik yöntemler ile analiz edilmesi daha gerçek sonuçlar sunmaktadır. Bu nedenle homojenlik testine gereksinim duyulmamıştır. Sosyal Bilimler alanında son yıllarda yapılan araştırmalarda en çok tercih edilen non-parametrik yöntemlerin başında Mann-Kendall, Spearman'ın Rho'su Trend testleri gelmektedir. Bu yöntemler, yüksek tutarlılık seviyelerinden dolayı Dünya Meteoroloji Örgütü (WMO) tarafından önerilen istatistiki yöntemlerdir. Çalıșma kapsamında bu testler tercih edilmiștir. Mann-Kendall ve Spearman'ın Rho test analiz sonuçlarında Z kritik değer +-1,96 güven aralığında kaldığında eğilim görülmezken, bu değerin altına ya da 
üstüne çıktığında ise eğilim olduğu anlaşılmaktadır. Ayrıca ülkemizin yetiştirdiği bilim insanlarından Prof. Dr. Zekai Şen'in bilim dünyasına kazandırdığı “Şen Eğilim Metodu”da araştırmada uygulanmıştır.

\section{Mann-Kendall Testi (Mann-Kendall Test)}

Mann-Kendall, Kendall's Tau trend analizi olarak bilinen testin özel bir uygulamasıdır. Hidroklimatolojik nonparametrik verilerin kullanılmasından tercih edilen bir testtir. Var olan değişkenlerin yönü ve şiddetini belirlemede genel olarak tercih edilmektedir. Bu yöntemde peşi sıra dizilmiş verilerin analizinde kullanılmaktadır (Burn, 2002). Bu yöntemde zaman serisinde sıralanmış $\left(\mathrm{X}_{1}, \mathrm{X}_{2}, \ldots \ldots . . . . \mathrm{X}_{\mathrm{n}}\right)$ serilerin $\mathrm{H}_{0}$ sıfır hipotezine veriler zamana bağlı olmaksızın rastgele benzer dağılım göstermiş değişkenlerdir. $H_{1}$ alternatif hipotezine göre ise $(k \neq j)$ ve $n \geq k, j$ olmak üzere seride $X_{k}$ ve $X_{j}$ ardışık verilerin zaman serisinde dağılımı benzerlik göstermemektedir. Bunun sonucunda verilerde lineer bir eğilim var demektir. Mann-Kendall testinin test istatistiği S şöyle bulunmaktadır.

$$
\begin{array}{r}
\operatorname{sgn}\left(\mathbf{x}_{j}-\mathbf{x}_{\mathbf{k}}\right)=\left\{\begin{array}{l}
\left(x_{j}-x_{k}\right)>0 \Rightarrow+1 \\
\left(x_{j}-x_{k}\right)=0 \Rightarrow 0 \\
\left(x_{j}-x_{k}\right)<0 \Rightarrow-1
\end{array}\right\} \\
S=\sum_{k=1}^{n-1} \sum_{j=k+1}^{n} \operatorname{sgn}\left(x_{j}-x_{k}\right)
\end{array}
$$

Normal bir dağılım gösteren veriler ve ortalaması sıfır olan test istatistiği S’in varyansı, aşağıdaki formülle bulmaktadır.

$$
\operatorname{Var}(S)=\frac{n *(n-1) *(2 n+5)}{18}
$$

Var olan zaman serisindeki verilerde benzerlik olması durumunda, verilerin hesaplanmasında aşağıdaki formül kullanılmaktadır.

$$
\operatorname{Var}(S)=\frac{n(n-1)(2 n+5)-\sum_{t} t(t-1)(2 t+5)}{18}
$$

Hesaplanan veri setlerinde elde edilen sonuçlar, standart normal değişkenler hesaplanarak kritik değişken olan z ile karşılaştırılır.

$$
z=\left\{\begin{array}{lc}
S>0 \Rightarrow & \frac{S-1}{\sqrt{\operatorname{Var}(S)}} \\
S=0 \Rightarrow & 0 \\
S<0 \Rightarrow & \frac{S+1}{\sqrt{\operatorname{Var}(S)}}
\end{array}\right\}
$$

Mann-Kendall test analizinden sonra elde edilen sonuçlar eğer pozitif ise artan, negatif ise azalan yönde trend var demektir (Gümüş ve Yenigün, 2006; Yılmaz, 2018; Gözalan, 2019).

\section{Spearman'in Rho Testi (Spearman Rho Test)}

Spearman'ın Rho testi, iki parametre arasında var olan korelasyonu belirlemek için tercih edilen bir yöntemdir. Kullanışlı ve basit olmasından dolayı var olan eğilimlerin belirlenmesinde en çok tercih edilen yöntemlerden bir tanesidir. Sıra istatistiğini ifade eden Rxi'nin tespiti parametlerin büyükten küçüğe veya küçükten büyüğe doğru sıralanmasıyla gerçekleşir. Spearman'ın Rho testi istatistiğini rs ilişki değerleri aşağıdaki formülle hesaplanmaktadır (Gümüş, 2006). Bu analiz yönteminde xi sayısal değerlerinin (i=1,...n'e kadar) yerine veriler küçükten büyüğe ard arda sıralanmasıyla oluşturulan dizideki sıra numaraları kullanılmaktadır (Türkeş, 2013). rs ilişki katsayısı,

$$
r_{s}=1-6 \frac{\left[\sum_{i-1}^{n}\left(R\left(X_{\mathrm{I}-} i\right)^{2}\right)\right]}{n^{3}-n}
$$


formülü ile bulunmaktadır.

rs dağılımı n>30 olması durumunda normale yaklaşıyor demektir. Bu durumda rs istatistik analizleri için normal bir dağılım gösteren tablolardan yararlanılmaktadır. rs' nin test istatistiğine karşılık gelen $\mathrm{Z}$ değeri söyle hesaplanmaktadır (Gümüș, 2006).

$$
Z=r_{s} \sqrt{n-1}
$$

Denklemdeki hesaplamalar yapıldıktan sonra, elde edilen $\mathrm{Z} \alpha$ önem seviyesinde standart normal dağılım tablolarında gösterilen $\mathrm{Z} \alpha / 2$ değerinden daha büyük olması durumunda artış ya da azalış yönünde eğilimlerin olduğunu göstermektedir.

Analiz ile elde edilen sonuçlarda var olan eğilimlerin anlamlı olup olmaması son derece önemlidir. Sonuçların anlamlı olması için; rs > 0 olması durumunda eğilimin artış, rs < 0 ise eğilimin yönünde olduğu sonucuna varılmaktadır (Türkeş, 2013).

\section{Sen Testi (Sen Test)}

Kaydı tutulmuş meteorolojik veri serisi ortanca yıldan iki eşit yarıya ayrılır. Her iki alt-seri ayrı ayrı artan düzende sıralanır. Sonrasında ise ilk alt-seri (Xi) X-ekseni üzerinde ve ikinci alt seri (Xj) Y-ekseni üzerinde yer almak üzere Kartezyen koordinat sistemi üzerinde sıralanır. Eğer veri 1:1 doğrusunun üzerinde sıralanıyorsa, trend yok demektir. Eğer veriler 1:1 doğrusunun alt üçgen alanında yer alıyor ise, azalan bir trend olduğu; üst üçgen alanında yer alıyorsa, artan bir trend olduğu söylenebilir (Şen, 2012, 2013).

Şen'in yönteminin yenilikçi özelliği bütün veri aralıklarında yorumlanabilmesinde yatar. Bu metot, Şen tarafından (2013) Merkez/Bursa, Uludağ/Bursa, Fırat Nehri üzerinde, aynı metot, yine Şen tarafından (2012) Aslantaş Barajı, Menzelet Barajı ve Cizre istasyonunda, son olarak da Göztepe, Florya, Edirne, Bolu ve Bursa lokasyonlarındaki kaydedilmiş uzun dönemli sıcaklık verilerinin üzerinde uygulanmıştır, Şekil.1(Şen, 2013; Yıldırım, 2015).

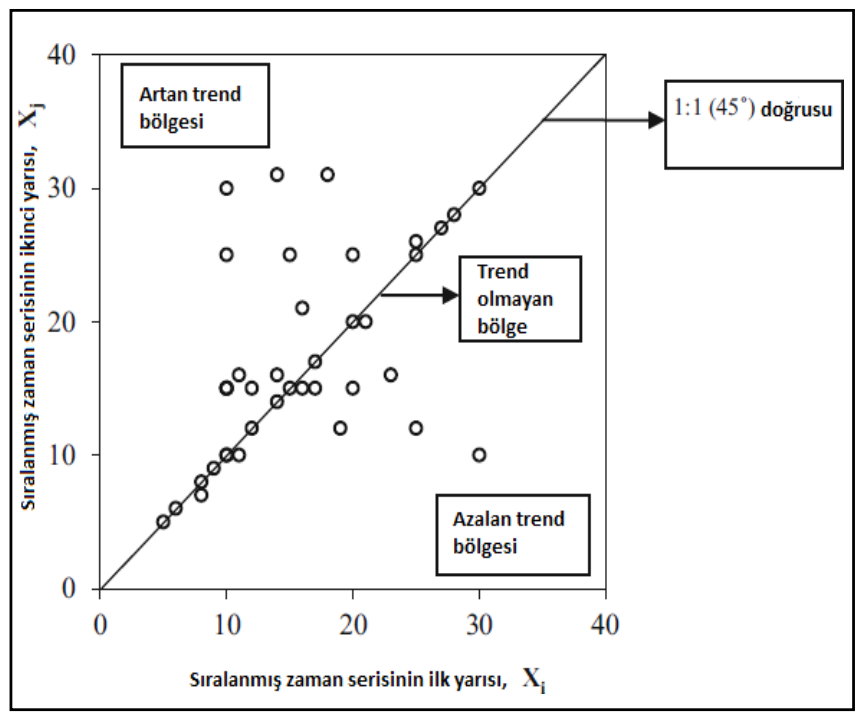

Şekil 2. Şen Metodu (Şen Method)

\section{Araştırma Bulguları (Experimental Results)}

Van Gölü Havzasındaki istasyonların ortalama yağış parametrelerindeki eğilimleri belirlemek amacıyla 19642017 yıllarını kapsayan veriler Mann-Kendall, ve Spearman'ın Rho'su Trend Eğilim testleri uygulanarak elde edilen bulgular Tablo 1'de verilmiștir.

Yıllık ortalama yağış değerlerinde Gevaş ve Ahlat istasyonlarında negatif eğilimler kuvvetli olup istatistiki açıdan anlamlılık ifade etmektedir. Erciş, Muradiye, Özalp ve Tatvan istasyonlarında negatif, Van-Bölge istasyonunda ise pozitif eğilimler görülmekte olup bu eğilimler istatistiki açıdan anlamlılık ifade etmemektedir. 
Tablo 1: Van Gölü Havzasının Ortalama Yağıș Verilerinin Mann-Kendall ve Spearman Testi Analiz Sonuçları (1964-2017) (Mann-Kendall and Spearman Test Analysis Results of Average Precipitation Data of Van Lake Basin "1964-2017”)

\begin{tabular}{|c|c|c|c|c|c|}
\hline Metod & \multicolumn{5}{|c|}{ Mann-Kendall ve Spearman'ın Rho's } \\
\hline Periyot & İlkbahar & Yaz & Sonbahar & Kış & Yıllık \\
\hline Van-Bölge & 1,50 & 0,01 & 0,86 & 0,42 & 1,25 \\
\hline Erciș & $\mathbf{- 2 , 7 1}$ & $\mathbf{- 2 , 3 7}$ & $\mathbf{- 3 , 5 7}$ & $\mathbf{- 3 , 8}$ & $-1,76$ \\
\hline Gevaș & $-1,11$ & $\mathbf{- 2 , 7 8}$ & $\mathbf{- 2 , 9 5}$ & $-1,39$ & $\mathbf{- 2 , 0 7}$ \\
\hline Muradiye & 0,00 & 0,33 & $-0,78$ & $\mathbf{- 2 , 6}$ & $-0,45$ \\
\hline Özalp & $-1,52$ & $\mathbf{- 3 , 4 2}$ & $-1,26$ & $-1,23$ & $-0,7$ \\
\hline Ahlat & $\mathbf{- 2 , 6 0}$ & $\mathbf{- 2 , 7 4}$ & $\mathbf{- 3 , 5 7}$ & $\mathbf{- 3 , 2 7}$ & $\mathbf{- 2 , 2 8}$ \\
\hline Tatvan & 0,61 & 0,00 & $-1,72$ & $-0,81$ & $-0,57$ \\
\hline
\end{tabular}

*\%95 (a=0.05) güven aralığında anlamlılık seviyesi belirtmektedir.

Mevsimlik yağış bulguları incelendiğinde, ilkbahar mevsiminde Ahlat ve Erciş istasyonlarında kuvvetli negatif yönlü eğilimler saptanmıştır. Geriye kalan istasyonlarda (Gevaş, Van-Bölge ve Özalp) var olan eğilimler ise anlamlılık göstermemektedir. Yaz mevsiminde Erciş, Gevaş, Özalp ve Ahlat istasyonlarında kuvvetli negatif yönlü eğilimler görülürken, Van-Bölge, Muradiye ve Tatvan istasyonlarında ise var olan eğilimler istatistiki açıdan anlamlılık ifade etmemektedir. Güz döneminde Erciş, Gevaş ve Ahlat istasyonlarında istatistiki açıdan kuvvetli negatif eğilimler saptanmıştır. Diğer istasyonlardaki eğilimler anlamlılık ifade etmemektedir. Kış döneminde Erciş, Muradiye ve Ahlat istasyonlarında negatif eğilimler görülürken geriye kalan istasyonlardaki eğilimler anlamlılık göstermemektedir.

Van Gölü Havzasında yıllık ortalama yağışların eğilim yönleri Şekil 2'de görüldüğü üzere genel olarak negatif yönlü eğilimlerin olduğu anlaşılmaktadır.

Şekil 3'te Şen trend analiz metoduna göre elde edilen yıllık trend bulguları; Van Gölü Kapalı havzasındaki yağış değerlerinde Gevaş ve Ahlat istasyonlarında yağışlarda anlamlı azalışların olduğu fakat diğer istasyonlarda ise anlamlı eğilimlere rastlanmadığı sonucuna varılmıştır. Elde edilen değerler Mann Kendall ve Spearman Rho test istatistiklerindeki sonuçlar ile de örtüștüğü görülmektedir. Gevaș ve Ahlat istasyonlarında değerlerin 1:1 doğrusundan saptığı ve eğilim yönünün negatife döndüğü gözlenmektedir. Fakat geriye kalan istasyonlardan VanBölge istasyonunda anlamlı olmayan artışlara, diğer istasyonlarda ise anlamlı olmayan azalışlara rastlanması değerlerin 1:1 doğrusuna çok yakın olmasından anlaşılmaktadır. Yani, belirtilen istasyonlarda belirli bir eğilim yönünün tam olarak olmadığı söylenebilir. 

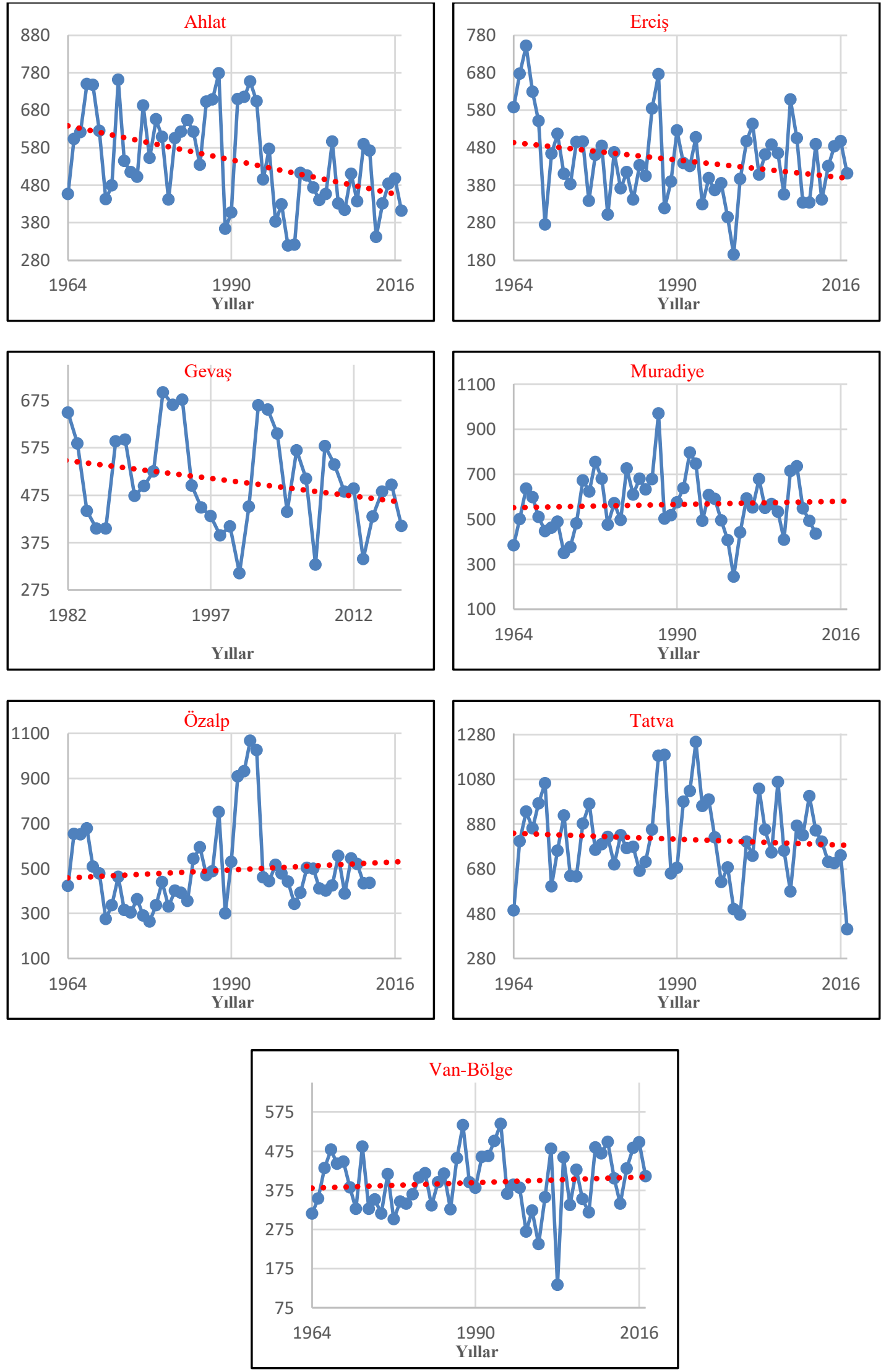

Şekil 3. Van Gölü Havzasındaki İstasyonların Ortalama Yağışların Eğilim Yönleri (1964-2017) (Trend Direction of Average Precipitation of the Stations in Van Lake Basin "1964-2017") 

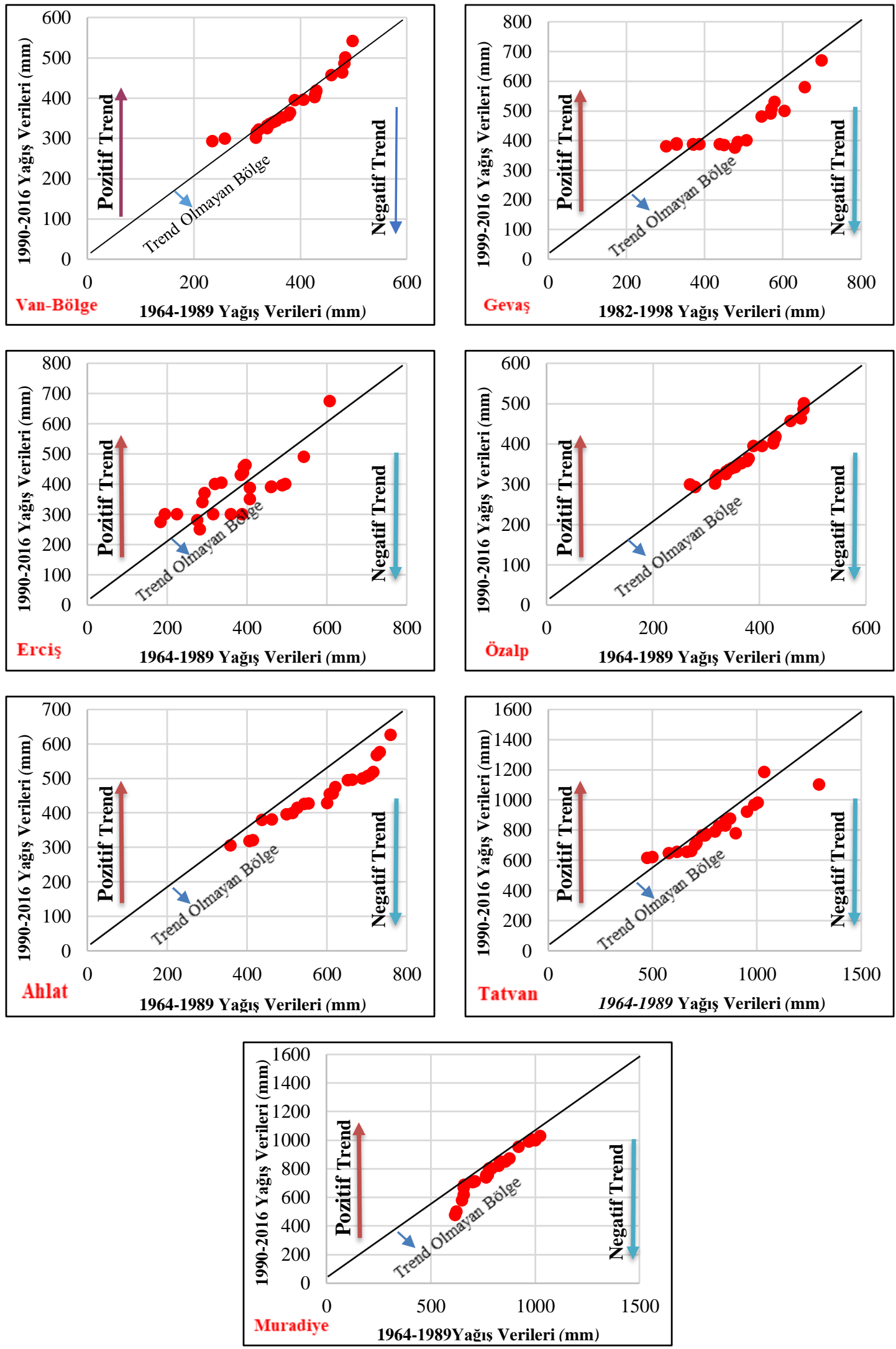

Şekil 4. Şen Eğilim Testine Göre Yağış Değerlerinin Trend Yönleri (Trend Directions of Precipitation Values According to Sen Trend Test) 


\section{Sonuç ve Tartışma (Result and Discussion)}

Van Gölü Havzasında bulunan 7 istasyonun bulgularına göre 1964-2017 yılları arasını kapsayan 53 yıllık periyotta yıllık ve mevsimlik ortalama yağıș verileri incelenerek Mann Kendall ve Spearman Rho test istatistiklerindeki sonuçlar verilmiştir (Tablo 2).

Tablo 2. Çalışma alanındaki istasyonların mevsimlik ve yıllık yağış eğilimleri (1964-2017) (Seasonal and annual precipitation trends of stations in the study area "1964-2017")

\begin{tabular}{|c|c|c|c|c|c|}
\hline Metod & \multicolumn{5}{|c|}{ Mann-Kendall ve Spearman'in Rho's } \\
\hline Periyot & İlkbahar & Yaz & Sonbahar & Kıș & Yillık \\
\hline Van-Bölge & ษ & 介 & 个 & 个 & 厄 \\
\hline Erciş & $\checkmark$ & $\checkmark$ & $\forall$ & $\nabla$ & $\sqrt{8}$ \\
\hline Gevaș & 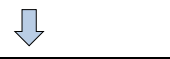 & $\sqrt{ }$ & $\forall$ & $\sqrt{b}$ & $\checkmark$ \\
\hline Muradiye & 0 & 0 & 0 & $\checkmark$ & 及 \\
\hline Özalp & Љ & $\forall$ & Љ & Љ & $\sqrt{\checkmark}$ \\
\hline Ahlat & $\forall$ & $\forall$ & $\downarrow$ & $\forall$ & $\forall$ \\
\hline Tatvan & 0 & 0 & $\sqrt{3}$ & $\sqrt{3}$ & $\S$ \\
\hline
\end{tabular}

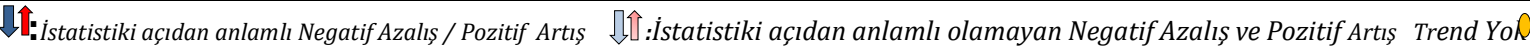

1964-1917 periyodunda Van Gölü Havzasının ortalama yağıș bulgularına göre; Mevsimlik olarak Van-Bölge ve Tatvan istasyonlarında var olan eğilimlerin istatistiki açıdan anlamlı olmadığı tespit edilmiştir, diğer istasyonlardan Ahlat ve Erciş'te dört mevsimde negatif, Gevaş'ta ise yaz ve sonbahar; Muradiye istasyonunda ise sadece kış mevsiminde istatistiki açıdan anlamlı negatif yönlü eğilimlerin olduğu görülmektedir. Özalp istasyonunda ise sadece anlamlı yağış azlığı yaz mevsimindedir.

Yıllık yağış değerlerinde ise Gevaş ve Ahlat istasyonlarında anlamlı negatif eğilimler görülürken, diğer istasyonlarda ise var olan yağış eğilimleri istatistiki açıdan anlamlılık ifade etmemektedir.

Şen eğilim metoduna göre yıllık olarak incelenen yağış trendleri, Van Gölü kapalı havzasındaki Gevaş ve Ahlat meteoroloji istasyonlarında negatif eğilimlerin olduğunu doğrulamaktadır. Diğer istasyonlardan Van-Bölge istasyonunda anlamlı olmayan yağış artışları gözlenirken havza genelindeki diğer istasyonlarda ise anlamlı olmayan negatif eğilimler tespit edilmiștir.

Emek (2014) Doğu Anadolu Bölgesi'nde yaptığı çalışmasında; 28 adet yağış gözlem istasyonunda azalan yönde bir eğilim, 10 adet yağış gözlem istasyonunda da artan yönde anlamlı olmayan bir eğilim gözlemiştir. Doğu Anadolu Bölgesi'nin kuzey kesimlerinde genellikle pozitif yönde trend görülürken, güney ve batı kesimlerinde negatif yönde trend tespit edildiğini belirtmiştir.

Yukarıda anlatılan sonuçlara göre havza genelinde anlamlı ya da anlamlı olmayan yağış azlığı eğilimi havzada kuraklık açısından bir riskin olduğunu göstermektedir. Keskin vd. (2018) çalışmalarında; Türkiye'nin iklim değişimlerinin yaşanabileceği riskli ülkelerden birisini oluşturmakta olduğunu, özellikle de ülkemizin doğu kesiminin iklim değişikliklerine çok duyarlılık gösterdiğini ve Doğu Anadolu Bölgesi'nin kuraklık açısından bir risk taşıdığını ileri sürmüşlerdir.

Kuraklık riski, göl seviyesinde meydana gelen değişimlerde sadece tektonik etkilerin değil, küresel iklim değişikliğinden kaynaklı yerel iklim parametrelerindeki değişimlerin de etkisinden söz edilebilir. Gelecekte iklim, tektonik kadar olmasa da göl seviye değişiminde tekrar etkili bir faktör olacağa benzemektedir. Aydın ve Doğu (2018) çalışmalarında; son yıllarda tüm dünyada olduğu gibi Van Gölü'nde de küresel iklim değişikliğine bağlı olarak az da olsa seviyede dalgalanmalar meydana gelmiştir. Küresel ısınma sonucunda yaşanan su kaybı sığ göllerde daha fazla iken derin göllerde daha azdır. Dolayısıyla Van Gölü gibi hem derin hem de alansal olarak büyük olan bir gölde küresel ısınmanın etkileri daha az hissedilmektedir, düșüncesini paylașmışlardır.

Yine Türkeş'e göre Türkiye'de yağış değişmeleri konusunda yaptığı çalışması incelendiğinde, yıllık yağışların azalma eğiliminde olduğu ve kurak dönemlerin 1970 sonrası arttığı ve gittikçe şiddetlendiği belirtilmektedir (Türkeș, 1996). Ayrıca, yağışlar kuzey yarımkürenin orta ve yüksek enlemlerinde her on yılda yaklaşık \%0,5 ile 
\%1 arasında artışa sahipken, Akdeniz havzasının da içinde olduğu subtropikal karaların önemli bir bölümünde her on yılda yaklaşık olarak \%3 azalma eğilimi görülmektedir (Türkeş vd., 2007).

Araştırma alanı, yukarıda belirtilen küresel ve yerel şartların etkisinde kalacağı ve küresel anlamda Akdeniz havzası ülkeleri, dolayısıyla ülkemiz için öngörülen senaryoların zaman içerisinde etkisinin gözleneceği olasıdır. Ancak belirtilen sonuçları kuvvetlendirecek çok daha güçlü kanıtlara da gereksinimin olduğu düşünülmektedir. Dünya da ve ülkemizde 1950 sonrası yaşanan hızlı şehirleşme ile meteorolojik istasyonların şehir hapsinde kalması ölçümlerin istemsiz manipülasyona uğramasına neden olabilir. Bu yüzden iklim çalışmalarının güçlü dayanaklarla temellendirilmesi; başka kanıtlara, veri kalitesini artırıcı unsurlara, başka ölçümlere ve çok parametreli araştırmalara ihtiyaç duyulmakta olduğu göz ardı edilmemelidir.

\section{Çıkar Çatışması (Conflict of Interest)}

Yazar tarafından herhangi bir çıkar çatışması beyan edilmemiştir. No conflict of interest was declared by the author.

\section{Kaynaklar (References)}

Ackerman, S. A. ve Knox, J. A. 2015. Meteoroloji Atmosferimizi Anlamak, Çeviri Ed. Mikdat Kadığlu-Sedef Çakır, Nobel Yayınları, Ankara.

Akköprü, E. 2019. Nemrut Volkanizması'nın Van Gölü Güneybatısı'ndaki Akarsu Sistemleri Üzerindeki Etkileri, Sosyal Bilimlerde Akademik Araștırmalar Kitabı, Ed. Zeki Taștan, Zeki Duman, Güler Yılmaz, Hiper Yayın, 205-222.

Aksoy, B. ve Coșkun, M. 2010. Global Climate Change and Its Effects on Turkey. EKEV Akademic Review "Social Sciences", 42, 367-382, Erzurum.

Aktaş, S., Kalyoncuoğlu, U. Y., Anadolu Kılıç, N.C., 2018. Eğirdir Göl Havzasının De Martonne Yöntemi ile Kuraklık Analizi, Journal of Engineering Sciences and Design, 6(2), 229 - 238.

Altan Aydın, F. 2017. Van Gölü Seviye Değişimleri ve Kıyılar Üzerindeki Etkileri, Van: Van Yüzüncü Yıl Üniversitesi Sosyal Bilimler Enstitüsü (Yayınlanmamış Yüksek Lisans Tezi).

Addisu, S., Selassie, Y.G., Fissha, G. ve Gedif, B. (2015). Time series trend analysis of temperature and rainfall in lake Tana Sub-basin, Ethiopia, Environmental Systems Research, pp. 4:25, Springer.

Asfaw, A., Simane, B., Hassen, A. ve Bantider, A. (2017). Variability and time series trend analysis of rainfall and temperature in northcentral Ethiopia: A case study in Woleka sub-basin, Weather and Climate Extremes, pp.1-13, Elsevier.

Avşaroğlu, Y. (2019). Dicle Havzası Aylık Ortalama Akım Değerlerinin Trend Analizi, H.Ü. Fen Bilimleri Enstitüsü yayımlanmamış Yüksek Lisans Tezi, Şanlıurfa.

Aydın, F. A. Ve Doğu, A. F. 2018. Göllerde Seviye Değișimleri ve Nedenleri: Van Gölü Örneği, 100. Yıl Üniversitesi Sosyal Bilimler Enstitüsü Dergisi, Sayı:41, sf:183-208, Van.

Blumenthal, M.M., Van der Kaaden, G., ve Vlodavetz, V.I., 1964. Catalogue of the active volcanoes of the World including solfatara fields. Part XVII Turkey and the Caucasus. International Association of Volcanology, 17, 1-23.

Burn, DH ve Elnur, MAH. 2002. Hidrolojik trendlerin tespiti ve değişkenlik. Hidroloji Dergisi, 255 (1-4), 107-122.

Coşkun, M. 2011. Fundamental pollutants in the European Union (EU) countries and their effects on Turkey. Elsevier, Procedia Social and Behavioral Sciences, 19, 467-473.

Coşkun, M. 2019. İklim Değișmeleri ve Küresel Isınma, 12. Bölüm, Yer Bilimi Kitabı, Ed. Mete Alim-Serkan Doğanay, Pegem Akademi, Ankara.

Coşkun, M., Aksoy, B. 2007. 19 Haziran 2004 Çubuk-Sünlü (Ankara) Hortum Olayı, Doğu Coğrafya Dergisi, 12(17), 203-222, Erzurum.

Coşkun M., Akbaş V. 2017. Karadeniz Kıyısından İç Kesime: Kastamonu Çevresinin İklim Parametreleri, Sosyal Bilimler Dergisi, The Journal of Social Science, Yll: 4, Sayı:11, Haziran 2017, s. 46-86.

Coşkun, S. 2020a. Tuz Gölü-Konya Kapalı Havzaları'nda Ortalama Sıcaklık, Yağıș Ve Akım Verilerinin Trend Analizi, Coğrafya Araștırmaları, Kitap Bölümü, 1. Bölüm, sf:1-13, Akademisyen Yayınevi (AYBAK), Ankara.

Coşkun, S. 2020b. Trend Analysis of Mean Temperatures Data in Van Lake Closed Basin, Turkey, Current Studies in Social Sciences, Chapter of Book, 3. Chapter, pp:43-51, Akademisyen Yayınevi (AYBAK), Ankara

Degens, E. T., Wong, H. K., Kempe, S., ve Kurtman, F., 1984. A geological study of Lake Van, eastern Turkey. Geologische Rundschau, 73-2, 701-734.

Emek, M.F., 2014. Doğu Anadolu Bölgesi Yıllık ve Aylık Toplam Yağışların Trend Analizi. Yayınlanmış Yüksek Lisans Tezi. Atatürk Üniversitesi Fen Bilimleri Enstitüsü, Erzurum.

Erlat, E., 2013. İklim Sistemi ve İklim Değișmeleri, Ege Üniversitesi Basımevi, İzmir.

Gözalan, S., 2019. Yüzey, 850, 700 ve 500 hPa Basınç Seviyelerinde Sıcaklık İle Nem Parametrelerinin Karşılaştırmalı Trend Analizi: Türkiye Örneği. Yayınlanmamış Yüksek Lisans Tezi, Karabük Üniversitesi Sosyal Bilimler Enstitüsü, Karabük.

Gümüş, V. 2006. Fırat Havzası Akımlarının Trend Analizi İle Değerlendirilmesi, Yüksek Lisans Tezi, Șanlıurfa: Harran Üniversitesi Fen Bilimleri Enstitüsü.

Gümüș, V., ve Yenigün, K., 2006. Evaluation of Lower Fırat Basin Streamflow by Trend Analysis. In 7th International Advances in Civil Engineering Conference, Yildiz Technical University, Istanbul, Turkey.

Kadıoğlu, M. 1997. Trends Surface Air Temperature Data Over Turkey", International Journal of Climatology, 17, $511-520$.

Kadıoğlu, M., Öztürk, N. ve Șen, Ş., 1999. On the precipitation climatology of Turkey by harmonic analysir, Internatiol Journal of Climatology, C. 19, ss. 1717-1728. 
Kamruzzamana, M., Beechama, S., ve Metcalfe, A. 2016. Estimation of trends in rainfall extremes with mixed effects models. Atmospheric Research, 168, 24-32.

Karabulut, M. ve Cosun, F. 2009. Kahramanmaraș İlinde Yağıșların Trend Analizi, Coğrafi Bilimler Dergisi, CBD 7(1), 65-83.

Karaosmanoğlu, F., Günek, H., 2018. Göksu Havzası'nda Buharlaşma ve Yüzeysel Akışın Penman ve Thourthwaite Yöntemlerine Göre Değerlendirilmesi. International Journal of Scientific and Technological Research, 4(10),599-614.

Kempe, S., Khoo, F., ve Gürleyik, Y., 1978. Hydrography of Lake Van and its drainage area. In: The Geology of Lake Van, E.T. Degens and F. Kurtman (eds.), The Mineral Research and Exploration Institute of Turkey (MTA) Publication No.169, pp. 3044.

Keskin M.E., Çakto İ., Çetin V., Bektaş O., 2018. Doğu anadolu Bölgesi Sıcaklık ve Yağış Trend Analizi, Journal of Engineering Sciences and Design, 6(2), 294-300.

Kızılelma, Y., Çelik, M. A., ve Karabulut, M., 2015. İç Anadolu Bölgesinde sıcaklık ve yağışların trend analizi. Türk Coğrafya Dergisi, (64), İstanbul.

Lazaro, R., Rodrigo, F.S., Gutierrez, L., Domingo, F. ve Puigdefabregas, J., 2001. Analysis of a 30-year rainfall record (1967-1997) in semi-arid SE Spain for Implications on Vegetation, Journal of Arid Environment, 48, 373- 395.

Nourani, V., Mehr, A. D. ve Azad, N., 2018. Trend Analysis Of Hydroclimatological Variables İn Urmia Lake Basin Using Hybrid Wavelet Mann- Kendall And Șen Tests. Environmental Earth Sciences, 77(5): 207.

Polat, P. ve Sunkar, M., 2017. Rize'nin İklim Özellikleri ve Rize Çevresinde Uzun Dönem Sıcaklık ve Yağış Verilerinin Trend Analizi, F.Ü. Sosyal Bilimler Dergisi, Cilt:27, Sayı:1, Sayfa:1-23, Elazığ.

Rahman, M. A., Yunsheng, L. Ve Sultana, N., 2017. Analysis And Prediction Of Rainfall Trends Over Bangladesh Using MannKendall, Spearman's Rho Tests And ARIMA Model. Meteorology and Atmospheric Physics, 129(4): ss.409-424.

Soydan, N.G., Gümüș, V., Șimșek, O., Gerger, R. ve Ağun, B., 2016. Seyhan Havzası Aylık Ortalama Akım ve Yağış Verilerinin Trend Analizi, D.Ü. Mühendislik Fakültesi Dergisi, c.7, s.2, ss. 319-327, Diyarbakır.

Sönmez, O., Ceribașı, G. ve Doğan, E., 2016. Short And Long Term Streamflow Prediction By Different Neural Network Approaches And Trend Analysis Methods: Case Study Of Sakarya River, Turkey. Fresen. Environ. Bull, 25: ss.565-579.

Şapolya, D., 2017. Ege Bölgesi sıcaklık Verilerinin Bölgesel Ortalama Menn Kendall Testi ile Trend Analizi, Yayınlanmış Yüksek Lisans Tezi. Çukurova Üniversitesi Fen Bilimleri Enstitüsü, Adana.

Şaroğlu, F., ve Yılmaz, Y., 1986. Doğu Anadolu'da neotektonik dönemdeki jeolojik evrim ve havza modelleri. Maden Tetkik ve Arama Dergisi, 107, 73-94.

Su, L., Miao, C., Kong, D., Duan, Q., Lei, X., Hou, Q. ve Li, H. (2018). Longterm Trends İn Global River Flow And The Causal Relationships Between River Flow And Ocean Signals. Journal of Hydrology, 563: ss. 818-833.

Şen, C. 2013. Isparta İlinde Sıcaklık ve Yağıș verilerinin Trend Analizi, Yayınlanmıș Yüksek Lisans Tezi. Süleyman Demirel Üniversitesi Sosyal Bilimler Enstitüsü Fiziki Coğrafya Anabilim Dalı, Isparta.

Şen, Z. 2012. Innovative trend analysis methodology. J. Hydrol. Engineering, 17(9), 1042- 1046.

Şen, Z. 2013. Trend identification simulation and application. J. Hydrol. Engineering doi: 10,1061/(ASCE) HE 19435584.0000811.

Şener, E., Şener, Ş., 2019. Meteorolojik Kuraklığın Coğrafi Bilgi Sistemleri Tabanlı Zamansal ve Konumsal Analizi: Çorak Gölü Havzası (Burdur-Türkiye) Örneği. Mühendislik Bilimleri ve Tasarım Dergisi, 7(3), 596-607.

Şenocak, S. ve Emek, M. F., 2019. Trend Analizi Yöntemleri Kullanılarak Doğu Anadolu Bölgesi Aylık Yağıș Miktarlarının Değerlendirilmesi, Avrupa Bilim ve Teknoloji Dergisi, Sayı: 17, Sayfa:807-822.

Tayanç, M., Karaca, M. ve Yenigün, O., 1997. Annual and Seasonal Air Temperature Trend Patterns of Climate Change and Urbanization Effects in Relation to Air Pollutants in Turkey, Journal of Geophysical Research, 102, 1909-1919.

Tosic, I. ve Ukasevic, M., 2005. Analysis of Precipitation Series for Belgrade, Theoretical and Applied Climatology, 80, 67 - 77.

Toros, H., 1993. Klimatolojik serilerden Türkiye ikliminde trend analizi, İ.T.Ü. Fen Bilimleri Enstitüsü, yayımlanmamış yüksek lisans tezi.

Türkeș, M., 1996. Spatial and temporal analysis of annual rainfall variations in Turkey, International Journal of Climatology, C. 16, ss. 1057-1076

Türkeș, M., 2012. Türkiye'de Gözlenen ve Öngörülen İklim Değișikliği, Kuraklık ve Çölleșme. Ankara Üniversitesi Çevrebilimleri Dergisi, 4(2), 1-32.

Türkeș, M., 2013. Klimatolojik Ve Hidrolojik Verilerin İklimsel Değişkenlik Analizi, Çanakkale Onsekiz Mart Üniversitesi Coğrafya Bölümü Fiziki Coğrafya Anabilim Dalı, Yayımlanmamış Ders Notları, Çanakkale.

Türkeș, M., Sümer, M., U. ve Kılıç, G., 1995. Variations and trends in annual mean air temperatures in Turkey with respect to climatic variability, International Journal of Climatology, C.15, S. 5, ss. 557-569.

Türkeș, M., Koç, T. ve Sarı, F., 2007. "Türkiye'nin YağıȘ Toplamı ve Yoğunluğu Dizilerindeki Değişikliklerin ve Eğilimlerin Zamansal ve Alansal Çözümlenmesi", Coğrafi Bilimler Dergisi, 3, 57-73.

Türkeş, M., Koç, T. ve Sarış, F., 2009. Spatiotemporal variability of precipitation total series over Turkey, International Journal of Climatology, C. 29, S.8, ss.1056-1074.

Wong, H.K., ve Finckh, P., 1978. Shallow structures in Lake Van. In: The Geology of Lake Van, E.T. Degens and F. Kurtman (eds.), The Mineral Research and Exploration Institute of Turkey (MTA) Publication, No.169, pp. 20-28.

Yenigün, K., Gümüş, V.ve Şimşek, O., 2013. Seyhan Havzası Gidişlerinin Analizi, VII. Ulusal Hidroloji Kongresi 26 -27 Eylül 2013 , Süleyman Demirel Üniversitesi, Isparta.

Yıldırım, A., 2015. Trend Analizi Yöntemleri: Orta Fırat Havzası Uygulaması, İstanbul Teknik Üniversitesi, Enerji Bilim ve Teknoloji Anabilim Dalı, Enerji Enstitüsü, Yayımlanmamış Yüksek Lisans Tezi, İstanbul.

Yılmaz, A., 2018. Batı Karadeniz Bölümünde Sıcaklık ve Yağıș Verilerinin Trend Analizi. Yayınlanmamıș Yüksek Lisans Tezi, Karabük Üniversitesi Sosyal Bilimler Enstitüsü, Karabük. 